ano 16 - n. 63। janeiro/março - 2016

Belo Horizonte I p. 1-262 I ISSN 1516-3210

A\&C - R. de Dir. Administrativo \& Constitucional

Revista de Direito ADMINISTRATIVO \& CONSTITUCIONAL

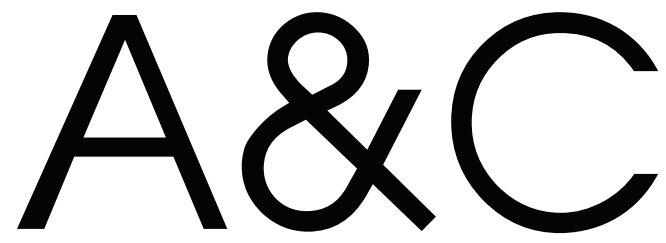




\section{A\&C - REVISTA DE DIREITO ADMINISTRATIVO \& CONSTITUCIONAL}

IPDA

Instituto Paranaense

de Direito Administrativo
ROMEU DELPE

BACELLAR

(c) 2016 Editora Fórum Ltda.

Todos os direitos reservados. É proibida a reprodução total ou parcial, de qualquer forma ou por qualquer meio eletrônico ou mecânico, inclusive através de processos xerográficos, de fotocópias ou de gravação, sem permissão por escrito do possuidor dos direitos de cópias (Lei no 9.610, de 19.02.1998).

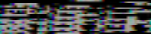

Luís Cláudio Rodrigues Ferreira

Presidente e Editor

Av. Afonso Pena, 2770 - 15a andar - Savassi - CEP 30130-012 - Belo Horizonte/MG - Brasil - Tel.: 08007043737 www.editoraforum.com.br / E-mail: editoraforum@editoraforum.com.br

Impressa no Brasil / Printed in Brazil / Distribuída em todo o Território Nacional

Os conceitos e opiniões expressas nos trabalhos assinados são de responsabilidade exclusiva de seus autores.

\begin{tabular}{|c|c|}
\hline A246 & $\begin{array}{l}\text { A\&C : Revista de Direito Administrativo \& } \\
\text { Constitucional. - ano 3, n. 11, (jan./mar. } \\
\text { 2003)- . - Belo Horizonte: Fórum, 2003- }\end{array}$ \\
\hline & 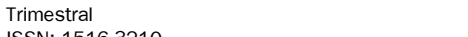 \\
\hline & $\begin{array}{l}\text { Ano 1, n. 1, } 1999 \text { até ano 2, n. 10, } 2002 \text { publicada } \\
\text { pela Editora Juruá em Curitiba }\end{array}$ \\
\hline & $\begin{array}{l}\text { 1. Direito administrativo. } 2 \text {. Direito constitucional. } \\
\text { I. Fórum. }\end{array}$ \\
\hline & $\begin{array}{l}\text { CDD: } 342 \\
\text { CDU: } 342.9\end{array}$ \\
\hline
\end{tabular}

Coordenação editorial: Leonardo Eustáquio Siqueira Araújo Capa: Igor Jamur

Projeto gráfico e diagramação: Walter Santos

\section{Periódico classificado no Estrato A1 do Sistema Qualis da CAPES - Área: Direito.}

Revista do Programa de Pós-graduação do Instituto de Direito Romeu Felipe Bacellar (Instituição de Pesquisa e Pós-Graduação), em convênio com o Instituto Paranaense de Direito Administrativo (entidade associativa de âmbito regional filiada ao Instituto Brasileiro de Direito Administrativo). A linha editorial da $A \& C$ - Revista de Direito Administrativo \& Constitucional segue as diretrizes do Programa de Pós-Graduação do Instituto de Direito Romeu Felipe Bacellar em convênio com o Instituto Paranaense de Direito Administrativo. Procura divulgar as pesquisas desenvolvidas na área de Direito Constitucional e de Direito Administrativo, com foco na questão da efetividade dos seus institutos não só no Brasil como no direito comparado, com ênfase na questão da interação e efetividade dos seus institutos, notadamente América Latina e países europeus de cultura latina.

A publicação é decidida com base em pareceres, respeitando-se o anonimato tanto do autor quanto dos pareceristas (sistema double-blind peer review).

Desde o primeiro número da Revista, $75 \%$ dos artigos publicados (por volume anual) são de autores vinculados a pelo menos cinco instituições distintas do Instituto de Direito Romeu Felipe Bacellar.

A partir do volume referente ao ano de 2008 , pelo menos $15 \%$ dos artigos publicados são de autores filiados a instituições estrangeiras.

Esta publicação está catalogada em:

- Ulrich's Periodicals Directory

- RVBI (Rede Virtual de Bibliotecas - Congresso Nacional)

- Library of Congress (Biblioteca do Congresso dos EUA)

A\&C - Revista de Direito Administrativo \& Constitucional realiza permuta com as seguintes publicações: - Revista da Faculdade de Direito, Universidade de São Paulo (USP), ISSN 0303-9838

- Rivista Diritto Pubblico Comparato ed Europeo, ISBN/EAN 978-88-348-9934-2 
Diretor-Geral

Romeu Felipe Bacellar Filho

Diretor Editorial

Paulo Roberto Ferreira Motta

Editores Acadêmicos Responsáveis

Daniel Wunder Hachem

Ana Cláudia Finger

Assessor Editorial

Felipe Klein Gussoli

\section{Conselho Editorial}

Adilson Abreu Dallari (PUC-SP) Juan Pablo Cajarville Peluffo (Universidad de La República - Uruguai) ardo Schier (Instituto Bacellar) Justo J. Reyna (Universidad Nacional del Litoral - Argentina)

Alice Gonzalez Borges (UFBA) Juarez Freitas (UFRGS)

Carlos Ari Sundfeld (FGV-SP) Luís Enrique Chase Plate (Universidad Nacional de Asunción - Paraguai)

Carlos Ayres Britto (UFSE) Marçal Justen Filho (UFPR)

Adriana da Costa Ricardo Schier (Instituto Bacellar)
Alice Gonzalez Borges (UFBA)

Marcelo Figueiredo (PUC-SP)

Márcio Cammarosano (PUC-SP)

Carlos Delpiazzo (Universidad de La República - Uruguai) Cármen Lúcia Antunes Rocha (PUC Minas) Célio Heitor Guimarães (Instituto Bacellar) Celso Antônio Bandeira de Mello (PUC-SP) Clèmerson Merlin Clève (UFPR) Clovis Beznos (PUC-SP) Edgar Chiuratto Guimarães (Instituto Bacellar) Maria Cristina Cesar de Oliveira (UFPA)

Nelson Figueiredo (UFG)

Odilon Borges Junior (UFES)

Pascual Caiella (Universidad de La Plata - Argentina)

Emerson Gabardo (UFPR)

Paulo Eduardo Garrido Modesto (UFBA)

Paulo Henrique Blasi (UFSC)

Enrique Silva Cimma (Universidad de Chile - Chile) Eros Roberto Grau (USP)

Irmgard Elena Lepenies (Universidad Nacional del Litoral - Argentina) de La Coruña - Espanha)

Pedro Paulo de Almeida Dutra (UFMG)

Regina Maria Macedo Nery Ferrari (UFPR)

Rogério Gesta Leal (UNISC)

Rolando Pantoja Bauzá (Universidad Nacional de Chile - Chile)

Sergio Ferraz (PUC-Rio)

Valmir Pontes Filho (UFCE)

José Eduardo Martins Cardoso (PUC-SP)

José Luís Said (Universidad de Buenos Aires - Argentina) José Mario Serrate Paz (Universidad de Santa Cruz - Bolívia)

Yara Stroppa (PUC-SP)

\section{Homenagem Especial}

Guillermo Andrés Muñoz (in memoriam) Jorge Luís Salomoni (in memoriam) Julio Rodolfo Comadira (in memoriam) Lúcia Valle Figueiredo (in memoriam)

Manoel de Oliveira Franco Sobrinho (in memoriam) Paulo Neves de Carvalho (in memoriam) 


\title{
O reflexo das crises interconectadas do Estado contemporâneo na transformação dos direitos humanos fundamentais sociais
}

\begin{abstract}
Yuri Schneider
Professor do Programa de Pós-Graduação (Mestrado) da Universidade do Oeste de Santa Catarina - Unoesc (Chapecó - SC, Brasil). Doutor e Mestre em Direito Público pela Unisinos (Capes conceito 6). Professor de Graduação e Pós-Graduação da Fundação Escola Superior do Ministério Público do Estado do Rio Grande do Sul. Professor da Escola Superior da Magistratura Federal do Rio Grande do Sul. Professor da Escola Superior de Direito Municipal de Porto Alegre - RS. Professor da Fundação Escola Superior da Defensoria Pública do Estado do Rio Grande do Sul. Advogado. E-mail: <yurisdr@hotmail.com>.
\end{abstract}

\section{Rogério Luiz Nery da Silva}

Professor de Pós-Graduação na Universidade do Oeste de Santa Catarina - Unoesc (Chapecó SC, Brasil). Doutor em Direito Público e Evolução Social (Unesa - Capes conceito 5) - Direitos Sociais e Políticas Públicas. Mestre em Direito e Economia (UNIG), área Direito Internacional e Direitos Humanos. Mestre em Comunicações (ESAO). Professor de Pós-Graduação na Escola da Magistratura do Estado do Rio de Janeiro (Emerj), na Fundação Escola Superior do Ministério Público do Rio de Janeiro (Femperj), na Fundação Escola Superior da Defensoria Pública do Estado do Rio de Janeiro (Fesudeperj), e nas universidades Gama Filho (UGF), Veiga de Almeida (UVA), Cândido Mendes (UCM), Estácio de Sá (Unesa) e Castelo Branco (UCB), nesta última, na modalidade ensino a distância (EAD). E-mail: <yurisdr@hotmail.com>.

Resumo: Este estudo tem como objetivo evidenciar como as crises pelas quais passa o Estado contemporâneo influenciam na efetivação dos direitos fundamentais sociais, bem como nos princípios da dignidade da pessoa humana e, principalmente, no princípio da igualdade. Procura-se, assim, demonstrar que os direitos fundamentais podem vir expressos tanto em princípios como em regras constitucionais, e que a igualdade, direito fundamental de primeira dimensão, não pode ser compreendida sob uma ótica puramente formal-subjetiva, própria do liberalismo. Conclui-se, então, que é imprescindível que o Estado deixe sua posição de neutralidade, cuja insuficiência já foi cabalmente constatada, e passe a promover a igualdade material-objetiva.

Palavras-chave: Crises do Estado. Direitos fundamentais. Princípio da igualdade. Princípio da dignidade da pessoa humana.

Sumário: 1 Notas introdutórias - 2 Crises interconectadas do Estado: conceitual, estrutural, constitucional (institucional), funcional e política $\mathbf{-} \mathbf{3}$ Direitos sociais fundamentais(?) As dificuldades de estabelecimento e asseguração dos direitos sociais como direitos humanos fundamentais sociais, essenciais para a eficácia dos princípios da dignidade da pessoa humana e do princípio constitucional da igualdade, frente a um processo incessante de globalização com plataforma neoliberal - $\mathbf{4}$ Considerações finais - Referências 


\section{Notas introdutórias}

A constante evolução do conceito de Estado é tema complexo, fundamentalmente em face das suas constantes modificações, pois o Estado contemporâneo passa, ainda hoje, por diversas transformações, refletidas pelas denominadas "crises interconectadas". ${ }^{1}$

A luta pela construção de um Estado comprometido com a realização dos direitos e garantias fundamentais, sobremaneira dos direitos humanos, objetos desta pesquisa, e as barreiras enfrentadas para sua manutenção são desafios constantemente abordados pela teoria crítica do direito e do Estado.

O Estado contemporâneo passa por um momento marcado por um forte antagonismo: de um lado, constitui-se numa associação política de dominação, em que os governados se encontram sujeitos a uma ordem que confere legitimidade a tal domínio, acrescido o fato de a própria natureza humana inferir ao homem um comportamento voltado à busca do poder sobre todos; do outro lado, encontra-se marcado por princípios que amenizam e buscam minimizar essa dominação, através de institutos aperfeiçoantes do regime democrático, limitadores da expansão do poder do governante ou respectivo detentor do poder.

Tais princípios “democratizantes-liberais" têm a sua origem no momento histórico da própria Revolução Francesa, com o surgimento do Estado de Direito, como forma de limitar a ação do governante diante dos direitos do cidadão. Entretanto, tal limitação não significou, necessariamente, um avanço da própria democracia enquanto persecução da igualdade formal e material entre todos, na perspectiva dos direitos humanos.

Os debates em torno do remodelamento constante da democracia em busca de formas concretas que privilegiem a participação popular no maior número possível de momentos decisórios da atividade estatal advêm de uma crise de legitimidade por que passa o Estado contemporâneo.

Assim, inúmeros juristas fazem deste assunto alvo de suas inferências, principalmente tendo em vista as perniciosas consequências oriundas desse contexto, pois a perda de legitimidade por parte do poder estatal desconfigura a própria natureza do Estado enquanto persecutor do interesse público, com danos incomensuráveis à própria sociedade.

As transmutações ocorridas no Estado moderno, especialmente nas concepções do Estado absolutista - marcado pelo pensamento de Jean Bodin e Thomas Hobbes -, a superação deste mesmo Estado para o Estado de Direito, marcado pela liberdade

STRECK, Lenio Luiz; MORAIS, José Luis Bolzan de. Ciência política e teoria geral do Estado. 2. ed. Porto Alegre: Livraria do Advogado, 2001. p. 130. 
dos cidadãos em relação ao Estado e pela igualdade entre esses mesmos cidadãos, em que se encontram como expoentes John Locke e Immanuel Kant - foram efetivadas com o objetivo maior de limitar a ação do poder estatal, reduzindo-o ao mínimo, a fim de obter legitimidade, o que não era mais possível com o Estado absolutista.

Entretanto, há de se afirmar que houve inegáveis avanços em proveito da ordem econômica perquirida pela burguesia crescente, através de instrumentos que possibilitaram liberdade suficiente à necessária acumulação de capital do sistema capitalista. Tal contexto, ressalva-se, não obnubila os avanços do Estado de Direito em relação ao Estado absolutista.

Todavia, o crescimento das demandas sociais fez com que o Estado de Direito, também consignado enquanto um Estado liberal, fosse avolumado em um número de ações e atividades cada vez maiores, a fim de suprir as necessidades da sociedade tanto na área social quanto na econômica.

Da idealização de um Estado mínimo, passou-se a um Estado interventor, voltado à satisfação dos direitos fundamentais de primeira e segunda geração como o fomentador das atividades econômicas. Nessa senda, aduz José Afonso da Silva: ${ }^{2}$

Mas o Estado de Direito, que já não poderia justificar-se como liberal, necessitou, para enfrentar a maré social, despojar-se de sua neutralidade, integrar, em seu seio, a sociedade, sem renunciar o primado do Direito. O Estado de Direito, na atualidade, deixou de ser formal, neutro e individualista, para transformar-se em Estado material de Direito, enquanto adota uma dogmática e pretende realizar a justiça social.

Essa nova configuração estatal, essencial para uma legitimidade somente de um Estado capitalista, é denominada "Estado social de direito", que teve seu espaço solidificado do final do século XIX até a Segunda Guerra Mundial.

Num sentido de evolução constante do Estado, especialmente pelo fato de o Estado Social poder embasar regimes tanto democráticos quanto ditatoriais, surge o Estado Democrático de Direito, com a pontual característica de atuação do indivíduocidadão diretamente na gestão e no controle da Administração Pública. Mais do que isso, como afere José Luis Bolzan de Morais,

teria a característica de ultrapassar não só a formulação do Estado Liberal de Direito, como também a do Estado Social de Direito - vinculado ao welfare state neocapitalista - impondo à ordem jurídica e à atividade estatal um conteúdo utópico de transformação da realidade. ${ }^{3}$

2 SILVA, José Afonso da. Curso de direito constitucional positivo. São Paulo: Malheiros, 2001.

3 STRECK, Lenio Luiz; MORAIS, José Luis Bolzan de. Ciência política e teoria geral do Estado. 2. ed. Porto Alegre: Livraria do Advogado, 2001. p. 130. 
Essa configuração estatal tem por base uma ampliação significativa do princípio democrático, numa busca cada vez maior de legitimidade ao Poder Público, através da aproximação dos processos decisórios da sociedade civil. Todavia, há outras perspectivas quanto ao Estado Democrático de Direito, a exemplo da referida por Lenio Luiz Streck, configurando-o decisivamente pelo deslocamento do poder, que, no Estado de Direito, pertencia ao Legislativo (ordenador) e, no Estado Social, ao Executivo (fomentador).

No Estado Democrático de Direito, vê-se o deslocamento desse poder ao Judiciário, que se revela capaz de efetivar a implementação dos direitos sociais descritos na Carta Constitucional, haja vista "Inércias do Executivo e falta de atuação do Legislativo passam a poder ser supridas pelo judiciário, justamente mediante a utilização dos mecanismos jurídicos previstos na Constituição que estabeleceu o Estado Democrático de Direito". ${ }^{4}$

Não obstante essa dualidade de concepções, vê-se no Estado Democrático de Direito a subsunção dos avanços que acompanham o processo de transmutação do Estado (Estado de Direito e Estado Social de Direito), na busca da igualdade formal e material através de mecanismos, judiciais ou participativos, que possibilitam a efetivação dos direitos sociais.

A persecução dos fins do Estado Democrático de Direito tem de consubstanciarse na prática, sendo a participação popular um dos caminhos, não excludente de outros (como a via judicial), pois o Estado, como ordem coativa, conforme o modelo kelseniano, encontra-se em confronto com a sociedade, colocando em xeque a sua própria legitimidade. Até porque o Estado, em inúmeras situações, têm sido incapaz de atender às necessidades básicas da sociedade, inclusive as consubstanciadas nos textos constitucional e infraconstitucional, fato este que se dá, dentre outros, por uma crise estrutural ${ }^{5}$ do próprio Estado, bastando a análise dos direitos sociais consagrados no texto constitucional pátrio para obter uma exemplificação maior do referido, pois nessas se incluem as falsas promessas da modernidade ainda não consubstanciadas, como promessas de igualdade, liberdade, paz perpétua e dominação da natureza, surgidas nos primórdios do modernismo no século XV e que perseguem o Estado moderno. ${ }^{6}$

Essa constatação agrava ainda mais o quadro brasileiro, pois se dispõe de uma Constituição que externa o Estado Democrático de Direito como um princípio constitucional, mesmo sem a anterior concretização do Estado Social, criando um

\footnotetext{
STRECK, Lenio Luiz. Hermenêutica jurídica e $(m)$ crise - Uma exploração hermenêutica da construção do Direito. 3. ed. Porto Alegre: Livraria do Advogado, 2001. p. 93-94.

5 STRECK, Lenio Luiz; MORAIS, José Luis Bolzan de. Ciência política e teoria geral do Estado. 2. ed. Porto Alegre: Livraria do Advogado, 2001. p. 140.

6 SANTOS, Boaventura de Sousa. A crítica da razão indolente - Contra o desperdício da experiência. São Paulo: Cortez, 2000. p. 24.
} 
abismo social que deve ser superado a fim de se alcançar a própria efetivação do Estado Democrático de Direito.

\section{Crises interconectadas do Estado: conceitual, estrutural, constitucional (institucional), funcional e política}

As crises por que passa o Estado contemporâneo foram objetos de abordagem por vários autores da teoria do Estado e ciência política. No entanto, para os fins propostos neste estudo, adota-se como base a classificação realizada por José Luis Bolzan de Morais e Lenio Luiz Streck, na obra Ciência política e teoria geral do Estado, ${ }^{7}$ bem como outra obra do autor Bolzan de Morais, a qual seria uma continuação de seus estudos a respeito das crises do Estado em conjunto com a transformação histórica/constitucional dos direitos humanos, intitulada As crises do Estado e da Constituição e a transformação espacial dos direitos humanos, ${ }^{8}$ na qual se encontram detalhadamente as dificuldades enfrentadas pelos Estados nacionais, especialmente a partir das últimas décadas do século passado quando a crise da economia, e sobretudo as propostas para a sua superação, passam a interferir com vigor no aparelho estatal.

Assim, importa iniciar a abordagem sob a ótica da crise conceitual ${ }^{9}$ do edifício estatal, para o que se faz necessário atentar à ideia de que os conceitos de Estado e de direito têm sofrido drásticas modificações desde a segunda metade do século $X X$. Mais que isso, convém salientar que o contexto de discussão da crise conceitual do Estado está atrelado incondicionalmente a uma das bases do tripé do Estado moderno, o qual seria o tópico da soberania, visto esta ser o foco da crise abordada e, como foco em todo o mundo no seio do pensamento teórico, da esquerda à direita neoconservadora, a crise de um entendimento de soberania do Estado permanece sendo um grande desafio a ser enfrentado na recente virada do século, principalmente tocante à promoção e proteção dos direitos humanos.

Tem-se, assim, a clara ideia de que as crises do Estado mantêm suas raízes não somente em crises de natureza econômica ou financeira, senão porque se trata de uma crise de identidade estatal, o que torna fácil a explicação da existência desta crise latente no Estado contemporâneo, principalmente de seu conceito, quando se tem presente na realidade atual a transformação de tempo e do espaço em uma velocidade estrondosa. Isso porque as informações contemporâneas, utilizando

\footnotetext{
STRECK, Lenio Luiz; MORAIS, José Luis Bolzan de. Ciência política e teoria geral do Estado. 2. ed. Porto Alegre: Livraria do Advogado, 2001. p. 140.

8 MORAIS, José Luiz Bolzan de. As crises do Estado e da Constituição e a transformação espacial dos direitos humanos. Porto Alegre: Livraria do Advogado, 2002.

9 STRECK, Lenio Luiz; MORAIS, José Luis Bolzan de. Ciência política e teoria geral do Estado. 2. ed. Porto Alegre: Livraria do Advogado, 2001. p. 129.
} 
a novíssima tecnologia, rompem as fronteiras estatais, deixando clara a ideia de Octavio lanni, para quem não existe mais "sociedades nacionais", e sim a "sociedade global". ${ }^{10}$

Falar de soberania - tratada pela primeira vez em Les six livres de la Republique (1576), com Jean Bodin -, que mais tarde, caracterizando-se historicamente como um poder juridicamente incontrastável é, conforme o pensamento de Bolzan de Morais, ${ }^{11}$ falar de um saudosismo pela falta dos vínculos que circunscrevem esta soberania, pois, em verdade, o lato debate acerca da modernidade, como síntese histórica primaz das correções das injustiças sociais, remontando-nos a apontar o que afirmou Ernildo Stein, quando citou os dizeres de Jürgen Habermas ao colocar que a modernidade é um projeto inacabado. ${ }^{12}$

De fato, faz-se necessário o equacionamento crítico da soberania nacional (summa potestas), diante das vertiginosas mudanças culturais, tecnológicas, sociológicas, enfim, mudanças fronteiriças veladas, ou seja, pelas quais o sujeito cognoscente diante do desterritorializante processo de globalização e regionalização.

Dessa forma, para compreender o processo de crise soberana, deve-se atentar a essa caracterização do atual contexto da modernidade. Nesta senda, mostra-se interessante o entendimento de Zygmunt Bauman, ${ }^{13}$ para quem, a modernidade é "leve" e "líquida", e não mais uma modernidade "pesada" e "sólida", pois a leveza e a "fluidez" são associadas à mobilidade e à inconstância. Assim, a modernidade não foi fluida desde sua construção, mas acontece, sim, como um fenômeno contemporâneo, apontada na frase "derreter os sólidos", existente no Manifesto comunista. Para Bauman, porém, tal expressão não trazia o desejo de eliminá-los e construir um novo cenário sem sólidos, mas sim para “limpar a área para novos e aperfeiçoados sólidos; para substituir o conjunto herdado de sólidos deficientes e defeituosos por outro conjunto, aperfeiçoado e preferivelmente perfeito, e por isso, não mais alterável”.

O "derretimento dos sólidos" apresentou uma nova roupagem no atual contexto da modernidade, um sentido de nova formação de metas. Hoje, os "sólidos" de Bauman são os "padrões de comunicação e coordenação entre as políticas de vida conduzidas individualmente, de um lado, e as ações políticas de coletividades humanas, de outro".

E o debate que se coloca sobre a crise conceitual do Estado, mais precisamente quanto à ideia de soberania, no cenário da globalização e dos processos de integração, passa a ser exatamente o mesmo apontado nessas metáforas de Zygmunt Bauman,

\footnotetext{
10 IANNI, Octavio. A sociedade global. 11. ed. Rio de Janeiro: Civilização Brasileira, 2003. p. 35.

11 MORAIS, José Luiz Bolzan de. As crises do Estado e da Constituição e a transformação espacial dos direitos humanos. Porto Alegre: Livraria do Advogado, 2002. p. 26.

12 STEIN, Ernildo. Epistemologia e crítica da modernidade. 3. ed. ljuí: Editora Unijuí, 2001. p. 11.

13 BAUMAN, Zygmunt. Modernidade líquida. Rio de Janeiro: Jorge Zahar, 2001. p. 9-15.
} 
pois em se tratando da discussão da ideia de soberania estatal e reflexos das transformações de um Estado moderno, a comparação dos aspectos da modernidade com a realidade no Brasil resulta no pensamento de Streck, quando este aponta que no Brasil a modernidade é "tardia e arcaica”, pois há um "simulacro de modernidade", ou seja, as promessas de modernidade ainda não foram realizadas, razão pela qual a solução seria, para o autor, o retorno paradoxal ao Estado (neo)liberal.

Não obstante, a ideia de soberania, ao lado de povo e território, representou um dos alicerces tradicionais da formatação do Estado Moderno. No entanto, as noções de desterritorialização e reterritorialização, ínsitas ao fenômeno da globalização atual, redefinem os conceitos de soberania nacional, em especial quanto ao seu conteúdo. Assim, a soberania, como poder supremo, tornou-se elemento essencial do Estado moderno, inicialmente através da supremacia da monarquia com o rei sendo o detentor de vontade incontrastada diante de outros "poderes" da época, tais como a nobreza e senhores feudais. Ou seja, o poder era absoluto e perpétuo, pois não sofria qualquer limitação inclusive quanto à sua duração, submetendo-se apenas às leis divinas e naturais. Em um segundo momento, através de Rousseau, a soberania sai das mãos do rei e passa ao povo, que consubstancia a sua vontade geral no contrato originário do Estado e dá um caráter racional a este poder soberano. No decorrer do século XIX, ela se desenvolve para uma ideia de emanação do poder político e, posteriormente, passa à titularidade ao Estado.

Portanto, nas palavras de Bolzan de Morais, ${ }^{14}$ a soberania é, historicamente, um poder juridicamente incontestável, através do qual é possível definir e decidir acerca do teor e da aplicação das normas, notoriamente pela coercitividade destas em dado território. Essa definição expressa as dimensões da soberania adquirida/ construída pelo Estado moderno, ou seja, há uma soberania interna e uma externa.

A globalização e, posteriormente, o modelo neoliberal, com suas profundas transformações, não só econômicas, mas também no âmbito social e político, apresentam uma nova e inusitada realidade aos Estados nacionais, pois a descomunal força adquirida pelos conglomerados empresariais transnacionais e a formação das chamadas comunidades regionais (União Europeia, Nafta e Mercosul, por exemplo) teve papel fundamental na relativização da soberania estatal, porquanto o Estado vai continuamente perdendo a sua condição de centro único e autônomo de poder, sujeito exclusivo da política, único protagonista na arena internacional e ator supremo no âmbito do espaço territorial. ${ }^{15}$

É claro que o processo de globalização não foi montado todo de uma só vez, mas é certo que o processo se acirrou a partir do contexto do segundo pós-guerra.

\footnotetext{
14 MORAIS, José Luiz Bolzan de. As crises do Estado e da Constituição e a transformação espacial dos direitos humanos. Porto Alegre: Livraria do Advogado, 2002. p. 130.

15 MORAIS, José Luiz Bolzan de. As crises do Estado e da Constituição e a transformação espacial dos direitos humanos. Porto Alegre: Livraria do Advogado, 2002. p. 28.
} 
A partir de então, nesse momento de reconstrução do mundo, percebe-se uma forte tendência à internacionalização do capital, desenhada pela busca de espaços mais amplos e desregulamentados.

Assim, após despir-se de algumas de suas prerrogativas econômicas, políticas, culturais e sociais, o Estado é redefinido, debilitando-se. Por isso o mesmo esvai-se e acaba perdendo o seu escudo da soberania estatal. Por isso, não podemos nos atrelar à ideia de que o Estado possa desaparecer. Existe, sim, uma nova noção de sua dimensão, por seus elementos constitutivos não mais servirem para tal função.

Os paradigmas "povo, território e soberania", principalmente o último, devem ser revisitados, todavia, atentando para os reflexos negativos ao caráter social em um esfacelamento dos Estados nacionais, da cultura, da economia, da política e da personalidade. É claro que, com outras bases de apoio e não aquelas que, como comentado anteriormente, trazem-nos saudosismo, mormente falando do conceito de soberania. Daí porque a dita crise conceitual, que atinge indistintamente os Estados nacionais, com maior ou menor intensidade, pois estes já não conseguem dar conta da complexidade das estruturas institucionais que hoje se fazem necessárias. ${ }^{16}$ Assim, despontam as demais crises do Estado, quais sejam a estrutural, constitucional (institucional), funcional e política.

Em relação à crise estrutural ${ }^{17}$ do Estado, pode-se afirmar que o foco principal do debate gira em torno das críticas feitas à manutenção do Estado do Bem-Estar Social. Esse perfil estatal foi construído ao longo de anos de lutas sociais com intento de aperfeiçoar a regulação social, ou seja, incorporando na ideia de Estado o trato da regulação para a convencionalmente chamada questão social, até então não aplicado de forma efetiva no Estado liberal de Direito. Em razão dessas reivindicações o Estado vai agregar um sentido finalístico, adquirindo uma função social e transformandose em Estado Social ou Welfare State, obrigando-se a uma atuação interventivapromocional, ou seja, passa do Estado Mínimo àquele garantidor do bem-estar do cidadão.

Todavia, é importante frisar que, em um primeiro momento, a mudança de transformação da atuação do Estado, deixando este de ser mínimo, beneficia outros segmentos da sociedade que não somente as classes trabalhadoras, mas também apontou para outras circunstâncias como investimentos em estruturas básicas no processo produtivo industrial. ${ }^{18}$

\footnotetext{
16 MORAIS, José Luiz Bolzan de. As crises do Estado e da Constituição e a transformação espacial dos direitos humanos. Porto Alegre: Livraria do Advogado, 2002. p. 28.

17 MORAIS, José Luiz Bolzan de. As crises do Estado e da Constituição e a transformação espacial dos direitos humanos. Porto Alegre: Livraria do Advogado, 2002. p. 34-46.

18 MORAIS, José Luiz Bolzan de. As crises do Estado e da Constituição e a transformação espacial dos direitos humanos. Porto Alegre: Livraria do Advogado, 2002. p. 35.
} 
Já como outra circunstância, e não menos importante, ressalta-se a transformação no sentido de que a democratização dos movimentos sociais refletiu na abertura de outros caminhos, em que ficou estabelecido o crescimento das demandas por parte da sociedade civil. Vindo este aspecto a ser uma das principais problemáticas do próprio Estado de Bem-Estar, e vindo a confrontarem-se, pelo crescimento da atividade estatal, democracia e burocracia. ${ }^{19}$

A essência do Estado Social está calcada na ideia de intervenção porque a população tem direito a ser protegida, e independentemente de sua situação social ao indivíduo devem ser garantidos tipos mínimos de renda, alimentação, saúde, habitação, educação, sendo-Ihe assegurados não como caridade, mas como direitos políticos, ${ }^{20}$ o que vai exatamente na ideia de Bolzan de Morais, ${ }^{21}$ no momento em que aponta o Welfare State como o Estado em que o cidadão, qualquer que seja sua situação social, possui direito a ser protegido, por mecanismos públicos estatais.

A constitucionalização desse modelo estatal começa a ser construída com as constituições mexicana, em 1917, e a de Weimar, em 1919. Embora não uniformes, haja vista vincular-se intrinsecamente a uma conjuntura econômica específica, o Estado Social apresenta características que Ihe dão unidade: a intervenção do Estado, a promoção de prestações públicas e o caráter finalístico no sentido de cumprimento de sua função social. E é nesse momento que surge a questão: pode-se dizer que tais direitos mínimos estariam esgotando a matéria de uma chamada inclusão social?

Assim, o Estado de Bem-Estar Social estaria visando proteger o cidadão através de mecanismos contra ocorrências de curta ou longa duração, estando ligado diretamente à noção da efetivação dos direitos sociais fundamentais, visto estes terem como base a questão da igualdade.

Essa constante intervenção estatal com intuito social promoveu a democratização das relações sociais, o que vai desaguar na formulação de um Estado Democrático de Direito, que pode ser resumido como o aprofundamento do Estado de Direito e do Welfare State, pois, a par da questão social, agrega-se ou qualifica-se pela busca da igualdade. O conteúdo deste modelo representa um plus ao Estado Social, pois impõe à ordem jurídica e à ação estatal um conteúdo utópico de transformação do status quo.

Esse modelo de Estado, para sua institucionalização, seja como aprofundamento do liberalismo, seja como sua negação, caracterizou-se por crises, avanços e recuos, marchas e contramarchas. Contemporaneamente, seus maiores opositores encontram-se entre os denominados neoliberais, pois preconizam abertamente o fim

\footnotetext{
19 MORAIS, José Luiz Bolzan de. As crises do Estado e da Constituição e a transformação espacial dos direitos humanos. Porto Alegre: Livraria do Advogado, 2002. p. 28 e 36.

20 BOBBIO, Norberto. Dicionário de política. Brasília: UnB, 1986. p. 416.

21 MORAIS, José Luiz Bolzan de. As crises do Estado e da Constituição e a transformação espacial dos direitos humanos. Porto Alegre: Livraria do Advogado, 2002. p. 37-38.
} 
do Estado de Bem-Estar em face da alegada incompatibilidade funcional à era da globalização econômica.

O declínio dessa formulação estatal de bem-estar social foi permeado por outras crises, como aduz Bolzan de Morais, citando Pierre Rosanvalon, ${ }^{22}$ as quais seriam uma crise fiscal, uma crise ideológica e uma crise filosófica.

Inserida na crise estrutural, a crise fiscal-financeira, que para alguns está por trás de todas as críticas e revisões ao Estado Social, aparece já na década de 60, quando surgem os primeiros sinais de desequilíbrio entre receitas e despesas públicas. No início dos anos 70 , a crise do petróleo, que redundará numa crise econômica mundial, levará a um acréscimo das despesas públicas e, ao mesmo tempo - e também como consequência dessa desestruturação econômica -, à impossibilidade de um aumento da carga tributária em virtude das tensões sociais que caracterizaram esse período histórico. Isso resultará, como inescapável corolário, no crescimento do déficit público, haja vista que as demandas sociais aumentam em razão da recessão econômica mundial e, por outro lado, há a diminuição da arrecadação fiscal. Esses fatos - recessão econômica, debilidade pública e demandas sociais - foram grandes incentivadores do avanço das ideias neoliberais do "enxugamento" do Estado.

Ao final do século passado, a crise do Welfare State alcança os países centrais que se defrontam com demandas sociais há muito superadas, especialmente 0 desemprego. Nestes (os países centrais) e nos periféricos, as situações transitórias de dependência estatal, razão pela qual aquele modelo se impôs, se tornaram permanentes ou de longa duração. Por consequência, as políticas públicas para remediar essas necessidades sociais se transformaram, obrigatoriamente, em programas recorrentes de governo. Essa ampliação e duradoura despesa pública vai resultar em sucessivos déficits públicos, deixando muitas economias em verdadeiro estado "falimentar". As alternativas - de imediato encampadas pelo projeto neoliberal - situam-se ou no aumento da carga tributária ou na redução das despesas públicas ou, ainda, as duas concomitantemente. Essa terceira possibilidade é a que, paulatinamente, vem sendo aplicada, com o aval de instituições financeiras multilaterais, em diversas economias nacionais e, consequentemente, fulminando a continuidade do modelo estatal do Bem-Estar Social. Isso sem falar, é claro, da presença das novas tecnologias que transformaram o cenário de trabalho em filas enormes de desemprego e exclusão social.

A crise ideológica também é denominada crise de legitimação, haja vista que se estabelece em torno da capacidade de organização e gestão dessa forma estatal. Com efeito, a partir dos anos 80 , ocorre o embate entre a democratização do acesso

22 MORAIS, José Luiz Bolzan de. As crises do Estado e da Constituição e a transformação espacial dos direitos humanos. Porto Alegre: Livraria do Advogado, 2002. p. 39. 
ao espaço público da política, pois há o aumento de locus de participação política, o que impulsiona as demandas sociais, e, por outro lado, a burocratização para formular respostas a estas pretensões, ou seja, a política cede lugar à decisão tecnoburocrática. Saliente-se que não raras vezes a demanda política se vê frustrada pelo caráter técnico da solução apresentada. E, não podendo esquecer as palavras de Norberto Bobbio a esse respeito, "enquanto a democracia tem uma trajetória ascendente, a burocracia faz o percurso inverso, ou seja, descendente". ${ }^{23}$

Trata-se, por isso mesmo, de um processo peculiar de expansão jurídica, e até certo ponto revelador do grau de desarticulação organizacional do próprio Estado. É a crise generalizada do Estado brasileiro do ponto de vista de sua legitimidade, de sua capacidade funcional e de sua competência técnica - crise essa que se traduz pela sua flagrante incapacidade de exercer, de modo minimamente congruente, seus papéis de provedor de serviços básicos, promotor de novas relações sociais, planejador de atividades econômicas, produtor de bens estratégicos, prestador de serviços essenciais e executor de políticas sociais e programas de ajuste macroeconômicos.

No tocante à questão filosófica pode-se dizer que, acompanhando Bolzan de Morais, como consequência das anteriores, essa crise atinge o fundamento básico do Estado Social, qual seja: a solidariedade. A incapacidade do Estado de Bem-Estar Social em formular um protótipo antropológico que lhe desse sustentação, sobretudo dispondo sobre agentes dotados da compreensão coletiva, compartilhada e compromissada de ser-estar no mundo. 0 que se deu, na verdade, foi a transformação do indivíduo liberal em cliente da Administração, com a apropriação privada da poupança pública e distribuição clientelista das soluções estatais e dos serviços públicos.

É inevitável que todas as crises anteriores se reflitam no direito, principalmente no instrumento da modernidade no qual se estabeleceram os conteúdos políticos definidos pela sociedade como a organização do poder político e o asseguramento das liberdades - a Constituição.

$\mathrm{Na}$ atual conjuntura de crise estrutural do Estado, com este esgotado em seus aspectos financeiro, ideológico e filosófico, acreditamos que o direito deva responder, de um lugar afastado do Estado, estes clamores de uma sociedade que não tem esperanças de ver atendidas as políticas de inclusão social. Todavia, deve-se, para isso, atentar que esse mesmo direito deve ser visto, como Streck ${ }^{24}$ já referia, como instrumento de transformação social, pois essa é a ótica do modelo de Estado Democrático de Direito previsto em nossa Constituição, o que não ocorre por haver

\footnotetext{
23 BOBBIO, Norberto. O futuro da democracia. 7. ed. rev. e ampl. Tradução de Marco Aurélio Nogueira. São Paulo: Paz e Terra, 2000. p. 171.

24 STRECK, Lenio Luiz. Hermenêutica jurídica e $(m)$ crise - Uma exploração hermenêutica da construção do Direito. 3. ed. Porto Alegre: Livraria do Advogado, 2001. p. 33.
} 
uma disfuncionalidade do próprio direito das instituições que são responsáveis por aplicar a lei. Seguindo esse pensamento é que nos deparamos com a chamada crise constitucional ou institucional, principalmente porque a Constituição, sendo um documento jurídico-político, e estando sujeita às tensões sociais e ao jogo dos poderes, não pode se transformar em local de explicitação de programas de governo ao sabor dos influxos econômicos, sob pena de fragilizar-se como paradigma ético/ jurídico da sociedade e do poder, como bem aduz Bolzan de Morais. ${ }^{25}$

Todavia, é importante referir, antes de expormos os aspectos dessa crise constitucional, a presença latente de uma crise de uma legislação pátria como um todo, principalmente em se falando da legislação social, pois, como identifica Streck, "é importante observar, no meio de tudo isso, que, em nosso país, há até mesmo uma crise de legalidade, uma vez que nem sequer esta é cumprida, bastando, para tanto, ver a inefetividade dos dispositivos da Constituição". ${ }^{26}$

Tal crise de legalidade pode ser constatada quando se tem que, à sociedade, o Estado, diante da crescente inefetividade dessa legislação social, vem reagindo por meio da edição de sucessivas normas de comportamento, normas de organização e normas programáticas que, intercruzando-se continuamente, produzem vários sistemas legais.

O que se apresenta com isso é uma profunda mudança em nosso ordenamento jurídico, que tem como característica a ideia de um direito fechado, hierárquico e axiomatizado, substituído por um direito organizado em suas regras sob formas interrelacionadas com estas múltiplas cadeias normativas, que se entende consigam capturar, pragmaticamente, a complexidade da realidade socioeconômica.

E esse sistema normativo emergente cresce e se consolida a partir de uma tensa e intrincada pluralidade de pretensões materiais. A clássica distinção entre interesses privados comuns e coletivos, por exemplo, não é mais capaz de ocultar que, muitas vezes, a tutela legal de alguns é conflitante com a proteção de outros, mormente em se falando de políticas de inclusão social.

Com o crescimento desse modelo tem-se o aumento incessante de novas regras e matérias regulamentadoras, em que se constata o esvaziamento da função das leis e uma grande ampliação das obrigações desse rol legal, sendo repassado para a magistratura, para que essa possa livremente apresentar a argumentação e fundamentação de suas sentenças, onde teremos, por óbvio, a possibilidade de decisões divergentes entre si. E, além disso, temos presente a desvalorização da Constituição em preferência a essas (novas) legislações.

\footnotetext{
25 MORAIS, José Luiz Bolzan de. As crises do Estado e da Constituição e a transformação espacial dos direitos humanos. Porto Alegre: Livraria do Advogado, 2002. p. 47.

26 STRECK, Lenio Luiz. Hermenêutica jurídica e $(m)$ crise - Uma exploração hermenêutica da construção do Direito. 3. ed. Porto Alegre: Livraria do Advogado, 2001. p. 27.
} 
Por isso, num sistema jurídico formado de maneira viciada por leis de circunstância e regulamentos momentâneos de necessidade - condicionados por conjunturas específicas e transitórias -, a velocidade e a intensidade na produção de normas constitucionais, leis ordinárias, portarias, instruções normativas e decretos levam o Estado a perder a dimensão exata do valor jurídico tanto das regras quanto dos atos que disciplina.

Ao provocar a desvalorização do instrumental normativo que o Estado tem ao seu dispor, o tipo de legislação descrito nos dois últimos parágrafos tem sido um dos principais fatores responsáveis tanto pelo agravamento das tensões entre a estrutura do processo de negociações coletivas e o conflito distributivo aguçado pela crise econômica, quanto pelo crescente grau de inefetividade do poder de regulação, direção e intervenção do Estado nessa matéria.

No primeiro caso, essas tensões são apresentadas pelo fato de que, apesar dos esforços para ver suas demandas consagradas como direitos e convertidas em obrigações do Estado, os sindicatos, os movimentos comunitários, as entidades representativas, as associações religiosas e as corporações muitas vezes veem suas conquistas formalmente consagradas em textos legais não atendidos, ou seja, esvaziadas por um sistema jurídico que, de tanto ter ampliado seu número de normas, torna-se pesado, ineficaz e impotente.

$\mathrm{E}$, num segundo aspecto, quanto mais procura disciplinar e regular todos os espaços, dimensões e temporalidade do sistema econômico, convertendo numa complexa rede regulatória e de pequenos sistemas normativos esse ordenamento jurídico viciado (em termos de quantidade de regras e da variabilidade de suas formas) e dotado de um formalismo meramente de fachada (graças ao crescente recurso do legislador aos conceitos jurídicos indeterminados, às normas programáticas e às cláusulas gerais), menos o Estado parece capaz de expandir seu raio de ação e de mobilizar os instrumentos de que formalmente dispõe para exigir respeito a suas ordens.

Por isso que, nesse contexto, uma discussão que se impõe é a viabilidade de uma Constituição dirigente, como cunhou Canotilho, em sua obra Constituição dirigente e vinculação do legislador. ${ }^{27}$ Conforme o mestre lusitano, nesse tipo de Constituição o legislador ordinário já não é mais totalmente soberano em matéria de direito social e econômico, devendo suas decisões guiarem-se por princípios e diretrizes programáticas definidas pelo poder constituinte, os quais podem ter caráter negativo, mas principalmente positivo, pois estão voltados à consecução de determinadas metas e objetivos materiais. Os governos também ficam vinculados, sob pena de serem acionados judicialmente em face da inconstitucionalidade por omissão. Há, portanto, não uma intervenção estatal temporária ou excepcional,

\footnotetext{
${ }_{27}$ CANOTILHO, J. J. Gomes. Constituição dirigente e vinculação do legislador. contributo para a compreensão das normas constitucionais programáticas. Coimbra: Ed. Coimbra, 1998.
} 
mas sim uma regulação permanente, tornando-se uma obrigação constitucional aos dirigentes do Poder Executivo. ${ }^{28}$

Com a emergência do fenômeno da globalização neoliberal, há uma relativização da soberania do Estado em virtude da interpenetração das estruturas empresariais, a interconexão dos sistemas financeiros e a formação dos grandes blocos comerciais regionais. Estes se convertem em verdadeiros centros de poder, o que muitas vezes condiciona as ações estatais. Nesse sentido, adverte Faria que "o sistema político deixa de ser o locus natural de organização da sociedade por ela própria" e, "em vez de uma ordem soberanamente produzida, o que se passa a ter é uma ordem crescentemente recebida dos agentes econômicos". ${ }^{29}$

Por outro lado, não se pode olvidar que, mesmo no contexto da globalização atual, existe a supremacia constitucional, a força normativa da Constituição e a necessidade de uma Constituição vinculante e programática. Por isso que, finalizando o aspecto da crise constitucional ou institucional, decorrente da crise estrutural do Estado, urge a necessidade de uma racionalidade legal nova e capaz de dar conta do componente corporativista que vai caracterizando seu processo decisório; uma racionalidade forjada a partir da consciência, tanto dos legisladores quanto dos próprios líderes empresariais e trabalhistas, de que as formas de relações sociais condicionadas pela interconexão entre as grandes organizações exigem do Estado uma série de papéis originais de intermediação, que somente podem ser exercidos com a colaboração delas. Portanto, uma racionalidade responsável por uma legislação mais pragmática, apta a renunciar à regulação exaustiva dos processos sociais, voltando-se menos à consecução dos resultados concretos e mais à coordenação das diferentes formas de legalidade forjadas e desenvolvidas no interior dos vários subsistemas sociais.

Há que se repensar doutrinariamente o direito positivo a partir de paradigmas originais e sensíveis tanto à tendência das organizações à autonomia e à independência, na proporção direta de sua capacidade de mobilização, confronto e barganha, ${ }^{30}$ quanto à emergência dos novos institutos jurídicos especialmente voltados aos setores sociais marginalizados - aqueles que não têm condições de se integrar no processo de modernização econômica.

Esse novo tipo de racionalidade jurídica e essa nova forma de se repensar o direito justificam, no Brasil contemporâneo, em face da já mencionada ruptura da tradicional concepção piramidal do nosso sistema jurídico - um sistema que, tradicionalmente, tem sido apresentado como uma totalidade coerente, como uma ordem unitária que exclui a contradição e a descontinuidade, como um conjunto de normas hierarquizadas e solidárias, vinculadas por meio de relações lógicas e necessárias.

\footnotetext{
28 FARIA, José Eduardo. O direito na economia globalizada. 1. ed. São Paulo: Malheiros, 2002. p. 34.

29 FARIA, José Eduardo. O direito na economia globalizada. 1. ed. São Paulo: Malheiros, 2002. p. 35.

30 CAMPILONGO, Celso Fernandes. Os desafios do Judiciário: um enquadramento teórico. In: FARIA, José Eduardo (Org.). Direitos humanos, direitos sociais e justiça. São Paulo: Malheiros, 1994. p. 47.
} 
Daí a necessidade de se repensar não apenas o papel dos operadores do direito em seus diferentes níveis, mas o da própria organização judicial e da respectiva cultura técnico-profissional de seu corpo de magistrado, o que implica a necessidade de se tratar com profundidade o desafio da reordenação institucional do país, a fim de se evitar que, em nome da restauração da governabilidade, seja sutilmente promovida a desmontagem de importantes direitos sociais duramente conquistados pelas minorias segregadas após décadas de luta.

Com a mudança do pensamento sobre a aplicação da Constituição, da legislação infraconstitucional, e do direito como um todo, poderemos vislumbrar outras condições de possibilidade para a efetivação das políticas de inclusão social, pelas quais haverá uma transformação do imaginário social.

Outras duas crises também se apresentam como corolário das primeiras - a crise funcional e a crise política. A funcional representa, conforme Bolzan de Morais, ${ }^{31}$ a perda da exclusividade, apresentada na multiplicidade dos loci de poder, cria com isso um afastamento de centralidade e exclusividade do Estado. E essa perda de centralidade não pode ser analisada somente por um viés interno (separação/ harmonia das funções estatais), mas também, e muito importante nesse ponto, a sua análise externa, em que temos a invasão de um dos setores da estrutura tripartite, pelo outro, quando se tem, por exemplo, atividades do Legislativo sendo efetuadas pelo Executivo, como no caso das medidas provisórias, bem como quando o Estado perde a concorrência para outros setores. Isso nos traz a ideia de uma fragilização de um poder perante o outro.

Já em se tratando da crise política, salientar-se que o modelo de democracia representativa, como alternativa possivel em uma sociedade transformada historicamente, deixa claro um aspecto de impotência para dirimir as questões sociais. A democracia representativa apresenta-se como uma fórmula de pseudoditadura, em que durante quatro anos o candidato representante de seus eleitores atua da forma que bem entende sem haver a possibilidade de manifestação de seus próprios votantes, ou seja, com tal modelo se expressa um enfraquecimento do espaço público na política, conduzindo o cidadão a um processo de "apatia política diante da percepção da total desnecessidade mesmo dos próprios instrumentos de escolha dos representantes - as eleições". ${ }^{32}$

Para isso, acompanhamos a ideia de Bolzan de Morais, no que se refere à utilização de fórmulas da chamada democracia participativa, ${ }^{33}$ como alternativa

\footnotetext{
31 MORAIS, José Luiz Bolzan de. As crises do Estado e da Constituição e a transformação espacial dos direitos humanos. Porto Alegre: Livraria do Advogado, 2002. p. 50.

32 MORAIS, José Luiz Bolzan de. As crises do Estado e da Constituição e a transformação espacial dos direitos humanos. Porto Alegre: Livraria do Advogado, 2002. p. 50.

33 MORAIS, José Luiz Bolzan de. As crises do Estado e da Constituição e a transformação espacial dos direitos humanos. Porto Alegre: Livraria do Advogado, 2002. p. 57.
} 
possível de inserção dos cidadãos novamente no cenário político, ultrapassando os esquemas que caracterizam a democracia representativa, na qual o controle público é diminuído.

Aliás, não seria incorreto referir que essa seria a realidade de um sistema político estigmatizado por um profundo déficit de representatividade, gerado pela perversão da proporcionalidade na representação parlamentar no Congresso e pela incapacidade dos partidos de promoverem agregações de interesses; de um sistema econômico conhecido pela sua ineficiência na formulação, implementação e execução de políticas públicas; de um sistema social caracterizado por crescentes déficits de integração, uma vez que a pauperização de amplos contingentes populacionais, o desemprego e a inflação comprometem os padrões de coesão vigentes; e de um sistema cultural marcado por um déficit de motivação, revelado pelo descrédito com relação às instituições, pela descrença com relação a certos valores éticos e pela apatia.

Finalizando, entende-se que essas crises interconectadas do Estado podem ser consideradas o pano de fundo na fundamentação para o déficit crescente da inefetividade das políticas de inclusão social, haja vista, primeiro, a falta de sustentação no edifício estatal concretizado na questão da soberania e sua relativização (crise conceitual), segundo, a problemática estrutural do Estado, em se tratando das crises do Welfare State, como as crises fiscal, ideológica e filosófica, bem como do modelo que emerge como uma transformação da fórmula Estado de Direito/Welfare State, o qual seria o Estado Democrático de Direito, as quais apresentam uma perda de terreno para as ideias neoliberais de Estado mínimo, e, em um terceiro momento, uma crise institucional (constitucional), em que vislumbramos de maneira exacerbada uma desconstitucionalização, o desrespeito à Carta Maior, com a inefetividade dos direitos fundamentais, mormente se falando, o que é o cerne desta pesquisa, a inefetividade do princípio constitucional da igualdade em seu aspecto material.

\section{Direitos sociais fundamentais(?) As dificuldades de estabelecimento e asseguração dos direitos sociais como direitos humanos fundamentais sociais, essenciais para a eficácia dos princípios da dignidade da pessoa humana e do princípio constitucional da igualdade, frente a um processo incessante de globalização com plataforma neoliberal}

Depois de analisados os argumentos sobre crises do Estado, cabe abordar assunto que está ligado diretamente com a crise estrutural do Estado, bem como a crise constitucional, não afastando a interconexão existente dessas duas com as crises conceitual, funcional e política, como abordado anteriormente. 
Trata-se de abordagem sobre os direitos sociais previstos na Constituição Federal, inseridos na ordem dos direitos fundamentais e que são dispositivos consectários para a efetivação daqueles mencionados anteriormente, os quais seriam os princípios da dignidade da pessoa humana e do princípio constitucional da igualdade, não esquecendo a correlação com outros dispositivos não menos importantes, qual sejam, os objetivos fundamentais da República Federativa do Brasil (art. 3o, I, III e IV da $\mathrm{CF} / 88$ ), bem como os princípios seguidos pelo Brasil em suas relações internacionais, mormente se falando na prevalência dos direitos humanos (art. 4ํㅡㄴ II, da CF/88). Todavia, há quem diga que tais direitos não possam ser considerados como direitos fundamentais, pois não restariam elencados como direitos autoaplicáveis, visto estes dependerem da ação política do governo, não tendo, inclusive, instrumentos processuais constitucionais que possam obrigar sua aplicação no âmbito social.

Diferentes formas de argumentação se apresentam para sustentar a inconsistência dos diretos sociais como direitos humanos fundamentais, vale dizer, afirmados universalmente e consagrados no sistema jurídico nacional. Apesar disso, todas partem do pressuposto de que os direitos fundamentais sociais não são reconhecidos como verdadeiros direitos. E, uma das formas mais comuns de se negar efetividade aos direitos sociais, é retirar-lhes a característica de direitos fundamentais, ficando aqueles, assim, privados de aplicabilidade imediata, excluídos da garantia das cláusulas pétreas, tornando-se meras pautas programáticas.

Baseia-se nesses argumentos a doutrina jurídica atual, pelo nosso entendimento, para justificar modelos políticos sociais que se antepõem à ideia central do Estado Democrático de Direito, que afirma ser a observância dos direitos sociais uma exigência ética, não sujeita a negociações políticas. ${ }^{34}$ Para nós, não há dúvida de que os direitos sociais são uma forma de manifestação dos valores humanos da liberdade, igualdade e da dignidade da pessoa humana. Mesmo sabendo disso, é interessante desconstruir alguns argumentos que vão contra a ideia de que os direitos sociais devam ser considerados direitos humanos fundamentais. Aliás, várias são as questões que se colocam atualmente ao se tratar de direitos sociais, como direitos não elencados no rol dos "fundamentais". Ou seja, a ideia de alguns juristas é de que a questão dos direitos fundamentais, a partir do fenômeno citado, encontra-se num paradoxo entre um dinamismo essencial decorrente da própria noção de direitos fundamentais e uma necessidade de conservar a integridade e a credibilidade da tradição jurídico-teórica deles.

Para alguns autores, existe então um processo de multiplicação de novos direitos que conduzem a questionamentos a respeito da adequação desses direitos

\footnotetext{
34 CAMPILONGO, Celso Fernandes. O trabalhador e o direito à saúde: a eficácia dos direitos sociais e o discurso neoliberal. São Paulo: Revista dos Tribunais, 1995. p. 135.
} 
à característica "fundamental", ou seja, questiona-se se todos esses direitos são direitos fundamentais. Sob um outro enfoque, poder-se-ia falar que há um pensamento de desvalorização da noção de direitos fundamentais, isto é, ao se afirmar que todos esses direitos são direitos fundamentais, elevando à mesma categoria a liberdade de expressão (art. 5ำ, IV e IX da CF), o direito de proteção em face da automação

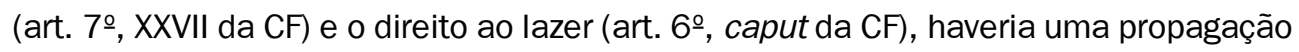
descabida da própria noção de direitos fundamentais. A partir dessas ideias, caberia, inclusive, distinções entre direitos mais fundamentais e direitos menos fundamentais. Afetados por essas tendências, há aqueles que, no intuito de conferir um critério para identificar os direitos fundamentais, acabam por afirmar que direitos fundamentais são aqueles reconhecidos pela Constituição como tal, ${ }^{35}$ reduzindo a noção de direitos fundamentais a um mero critério formal.

o que nos parece é que esse questionamento sobre a noção de direitos fundamentais advém do surgimento e da tipificação dos direitos sociais como direitos fundamentais. Somos levados a crer que talvez esteja aí o cerne das inquietações. Com isso, a ideia e o regime jurídico dos direitos sociais ficam prejudicados por uma profunda dificuldade que a doutrina possui em lidar com estes, perdendo a característica de valores supremos da ordem constitucional, consagrados na Lei Magna (arts. 6 a 11), pertencentes, assim, à categoria dos direitos fundamentais (Título I da Constituição de 1988).

Acaba que esses direitos se evidenciam rebaixados na norma constitucional, por uma hierarquia equivocada, em que ficam reduzidos a simples normas programáticas à espera de regulamentação para surtirem efeitos. E o ponto crucial do argumento, que não inclui na categoria dos direitos humanos (fundamentais) os direitos sociais, refere-se a sua universalidade. A teoria e a prática, sejam elas políticas e/ou legislativas, contestam essa universalidade, separando os direitos sociais dos direitos civis e políticos, estes, sim, entendidos sem discussão como fundamentais.

0 argumento mais difundido contra a natureza de direitos humanos dos direitos sociais refere-se à sua efetividade, pois os direitos sociais se diferenciariam dos direitos civis e políticos pelo fato de terem caráter programático, ou seja, os textos constitucionais ao regularem os direitos sociais estabeleceriam normas de caráter programático, que dependeriam de regulação infraconstitucional posterior e, por essa razão, esses direitos não teriam força de direitos públicos subjetivos.

Mas ao analisar a atual conjuntura, nem nesse aspecto os direitos fundamentais sociais têm sido observados na realidade brasileira. Na sua maioria, eles ainda continuam esperando regulamentação e, por isso mesmo, considerados pelos doutrinadores e até mesmo juízes como não obrigatórios de cumprimento. Ou seja,

\footnotetext{
35 MARTíN-RETORTILLO, Lorenzo. Regimen constitucional de los derechos fundamentales. Madrid: Civitas, 1988. p. 65.
} 
o detalhamento social dos direitos sociais passa a servir como mera decoração ao arranjo político que termina por preservar as desigualdades sociais que a própria constituição pretende corrigir. Assim, pode-se afirmar que a crítica ao caráter meramente formal das liberdades acabou por servir de fundamento político-jurídico para a instituição desses direitos.

$\mathrm{Na}$ senda desses fatores, várias constituições passaram a incluir no seu rol de direitos fundamentais os direitos sociais e econômicos, como exemplo, pioneiramente, a Constituição alemã de 1919, embora alguns indiquem a Constituição mexicana de 1917 como a precursora desse movimento. Já no Brasil, incutida no início da Era Vargas, tal tendência passou a se manifestar a partir da Constituição de 1934 quando, inovando no constitucionalismo pátrio, estabeleceu-se um novo título denominado "Da ordem econômica e social”. A Constituição de 1988, porém, foi mais incisiva. Além de conter em seu texto títulos referentes à ordem econômica e à ordem social, inscreveu os direitos sociais no título concernente aos direitos fundamentais. ${ }^{36}$

A rejeição política da obrigatoriedade dos direitos sociais pode ser baseada em argumentos teóricos e políticos, o que aqui passamos a expor aqueles que entendemos serem os mais utilizados pelos doutrinadores que vislumbram os direitos sociais longe da ideia de aplicabilidade como direitos humanos fundamentais. Num primeiro momento teríamos uma questão no âmbito do conflito dos direitos, ou seja, em um conflito entre os ditos direitos sociais e os já considerados fundamentais direitos civis e políticos. Basicamente essa questão apoia-se no fato de que, se os direitos sociais fossem considerados humanos/fundamentais, estariam colidindo com os direitos constitutivos do núcleo do Estado liberal, ou seja, as liberdades individuais e a propriedade. ${ }^{37}$

Outra teoria difundida para o rompimento da ligação dos direitos sociais com os direitos fundamentais seria o fato de alguns autores entenderem que aqueles seriam direitos de segunda ordem a serem, eventualmente, respeitados, ou seja, em caráter subsidiário aos direitos civis e políticos, mas nunca considerados fundamentais, por serem direitos que seriam aplicados somente em certas ocasiões em demandas sociais e econômicas, atentando sempre para a teoria da "reserva do possível", como sustenta Ricardo Lobo Torres. ${ }^{38}$

\footnotetext{
36 Como bem diria o eminente jurista português, Jorge Miranda, ao contrário das liberdades, os direitos sociais e econômicos pressupõem a existência de situações de desigualdade e necessidade entre os seres humanos, e têm por escopo alcançar uma igualdade efetiva através da intervenção do Estado (MIRANDA, Jorge. Os direitos fundamentais - Sua dimensão individual e social. Cadernos de Direito Constitucional e Ciência Política, n. 1, out./dez. 1992. p. 200.

37 KRELL, Andreas Joachim. Direitos sociais e controle judicial no Brasil e na Alemanha: os descaminhos de um direito constitucional “comparado". Porto Alegre: Sergio Antônio Fabris Editor, 2002. p. 47.

38 TORRES, Ricardo Lobo. A cidadania multidimensional na era dos direitos. In: TORRES, Ricardo Lobo (Org.). Teoria dos direitos fundamentais. 2. ed. Rio de Janeiro: Renovar, 2001. p. 262.
} 
Estes dois primeiros argumentos que apoiam a não ligação dos direitos sociais aos fundamentais estão difundidos na mesma ideia da cultura jurídica contemporânea, sendo que aquela encontra a sua formulação no argumento neoliberal de que os direitos sociais não passam de promessas vazias e que acabam sendo atentatórios às liberdades e direitos individuais.

Aliás, quando falamos em direitos humanos fundamentais, incluído nestes os direitos sociais, não podemos deixar de analisar as transformações e tendências de efetividade em nosso cenário, que é afetado em seu cunho social por um constante processo de globalização calcada no neoliberalismo.

Luis Roberto Barroso ${ }^{39}$ sustenta que, nessa linha de argumentação, muitas das normas constitucionais sobre direitos sociais, por não possuírem um mínimo de condições para a sua efetivação, acabam servindo como álibi para criar a imagem de um Estado que responde normativamente aos problemas reais da sociedade.

Um dos grandes desafios seria o rompimento/desconstrução dessas ideias equivocadas sobre a natureza dos direitos sociais, visto estarem diuturnamente influenciando o processo judicial, em que a grande parte da magistratura brasileira interpreta a Constituição baseada no formalismo jurídico positivista, pensamento este predominante na formação dos profissionais do direito de nosso país.

Nesse sentido, entendemos que o direito haveria de ultrapassar as feições de um ordenamento lógico-racional, de cunho liberal-individualista, assumindo estampas de um sistema diferenciado, não somente regulando as relações particulares, mas, também, solucionando conflitos de natureza social. Mas, infelizmente, a maioria dos juristas pátrios, com seus posicionamentos teóricos de matriz liberal-individualistanormativista, de caráter excessivamente dogmatizante, não tem mostrado alternativas (nem mesmo interesse) na construção do denominado Estado Democrático de Direito, mostrando assim a sua efetividade na concretização dos direitos sociais fundamentais.

O que acontece com essa postura é que não se permite a integração dos pontos de vista valorativos, ligados à justiça material no processo judicial, o que representa ignorar, no âmbito do Estado Democrático de Direito, a exigência estabelecida no próprio preâmbulo de nossa Constituição. É por isso que, sobre tal aspecto, acompanhamos o pensamento de Jorge Miranda ${ }^{40}$ que, pelo simples fato de essas normas integrarem texto constitucional, devem ser consideradas na interpretação das outras normas, podendo inclusive contribuir para o preenchimento de possiveis lacunas através de procedimentos de integração como a analogia. Entretanto, mais do que isso, e nesse aspecto seguimos o pensamento de Flávia Piovesan, ${ }^{41}$ para quem:

\footnotetext{
39 BARROSO, Luis Roberto. O direito constitucional e a efetividade de suas normas. Rio de Janeiro: Renovar, 2006. p. 61.

40 MIRANDA, Jorge. Manual de direito constitucional. 3. ed. Coimbra: Coimbra Editora, 2000. p. 250. v. IV.

41 PIOVESAN, Flávia. Organismos e procedimentos internacionais de proteção dos direitos econômicos, sociais e culturais. Rio de Janeiro: PUC-Rio, 2002.
} 
Os direitos sociais, econômicos e culturais são autênticos e verdadeiros direitos fundamentais. Integram não apenas a Declaração Universal, como ainda inúmeros outros tratados internacionais (ex: o Pacto Internacional dos Direitos Econômicos, Sociais e Culturais, a Convenção sobre a Eliminação da Discriminação Racial, a Convenção sobre os Direitos da Criança, a Convenção sobre a Eliminação da Discriminação contra as Mulheres). [...] Compartilha-se assim da noção de que os direitos fundamentais - sejam civis e políticos, sejam sociais, econômicos e culturais - são acionáveis, exigíveis e demandam séria e responsável observância.

Nesse ponto, alguns argumentos políticos se demonstram equivocados a respeito dos direitos humanos e sociais, pois guarnecem-se no fato de que os direitos sociais se encontram no estágio de sua justificativa e fundamentação recebendo, por isso, impedimentos quanto a sua implementação no Estado Democrático de Direito.

Um dos argumentos político-ideológicos afirma que, como os direitos sociais não participaram no momento fundador do Estado de Direito, assim como os direitos civis e políticos, não podem, desse modo, serem considerados como direitos de primeira ordem, mas, sim, de segunda. Todavia, no processo político, social e legislativo de democratização do Estado Liberal de Direito, o seu determinante foi a incorporação ao rol dos direitos humanos fundamentais, os direitos sociais. Na verdade, no contexto do Estado Democrático de Direito, a proteção dos direitos civis e políticos, originários do Estado Liberal Clássico, passou a pressupor a realização dos direitos sociais. Por isso mesmo eles não podem ser considerados direitos de segunda ordem, pois a própria natureza dos direitos civis pressupõe o seu engendramento através dos diretos sociais.

Por fim, trazemos à baila outro argumento utilizado equivocadamente e que tem o intuito de afastar os direitos sociais do rol dos diretos humanos fundamentais - seria a alegação de um elevado custo orçamentário que aqueles direitos despenderiam para o Estado. E, mais uma vez aqui, apoiando-se na teoria da "reserva do possivel", é um argumento que tem como raízes o pensamento neoliberal contemporâneo. Essa teoria, arraigada em uma ilusória racionalidade que a caracteriza como limite fático à efetivação dos direitos sociais prestacionais, ignora em que medida o custo é consubstancial a todos os direitos fundamentais, e não somente aos direitos sociais.

Já como primeiro contraponto a esse argumento estaria o fato de que aqueles que defendem esse ponto de vista não atentam para o alto custo que o edifício estatal tem como necessário para garantir os direitos civis e políticos. Ou seja, a escassez de recursos como argumento para a não aplicação dos direitos sociais como direitos humanos fundamentais afetaria tanto os direitos civis e políticos, exaltados pelo Estado Liberal de Direito, como os direitos sociais; tal argumento ameaça a existência de todos os direitos. É como se no sistema jurídico só fosse possível dirimir solução em igualdade absoluta esquecendo as desigualdades sociais. 
Após expor alguns dos argumentos que primam pelo afastamento dos direitos sociais da seara dos direitos humanos fundamentais, é importante firmarmos nosso entendimento, visto ser contrário àqueles, vislumbrando serem os direitos sociais de suma relevância como direitos fundamentais, por se tratarem de instrumentos de manifestação e efetivação do princípio da dignidade da pessoa humana e do princípio constitucional da igualdade material, mormente em se falando em políticas públicas de inclusão social.

A Constituição de 1988 objetivou, ao adotar o Estado Democrático de Direito, determinado processo de transformação social, que não consegue ser efetivado de forma prática e real. Contudo, diante de um paradigma de transformação social/ globalização e de realização do Estado Democrático de Direito, temos que essa globalização preferencialmente econômica, com plataforma neoliberal, é um dos elementos que impedem a construção daquele modelo de Estado.

0 "velamento" ${ }^{42}$ das normas que propiciam a construção desse "novo" modelo de Estado é feita, sim, de maneira ciente, por determinado paradigma de sociedade/ globalizada do próprio direito, que gera um Estado cada vez menos comprometido com a realização dos direitos humanos (sociais fundamentais!), já que não são premissa de um modelo liberal-individualista.

O Estado, assim, não intervém como deveria proceder, olvidando-se do cunho social expresso na Constituição Federal de 1988, qual seja o denominado Estado Democrático de Direito. Ora, o constituinte ao elencar os valores supremos do Estado Democrático de Direito considerou os direitos sociais como categoria jurídica essencial do regime que pretendeu estabelecer através da Constituição, e, portanto, pertencentes à mesma categoria hierárquica dos direitos civis e políticos, ou seja, o próprio constituinte quando procedeu dessa maneira colocou os direitos sociais como direitos fundamentais que mantêm relações de igualdade com os direitos civis e políticos.

A dificuldade de vislumbrar tal aspecto está naquilo que Lenio Streck referia quando esse tipo de organização estatal pressupõe para sua plena realização uma hermenêutica peculiar, que supera a "hermenêutica constitucional" (a técnica própria e específica de interpretar a Constituição) tradicional, diferenciando-se em virtude de ser uma hermenêutica em que a Constituição é vista como "uma ferramenta que está à 'disposição' do intérprete", sendo na linguagem heideggeriana um modo-de-ser-no mundo do intérprete. ${ }^{43}$

\footnotetext{
42 STRECK, Lenio Luiz. Hermenêutica jurídica e $(m)$ crise - Uma exploração hermenêutica da construção do Direito. 3. ed. Porto Alegre: Livraria do Advogado, 2001. p. 138.

43 STRECK, Lenio Luiz. Jurisdição constitucional e hermenêutica - Uma nova crítica do direito. Porto Alegre: Livraria do Advogado, 2002. p. 194 -198.
} 
Uma Constituição, enquanto fórmula política simbolizadora do pacto social, deve possuir um comprometimento com a realização e garantia dos direitos fundamentais, sejam os de primeira geração, como os direitos e liberdades individuais, sejam os de segunda geração como os direitos sociais e econômicos e de terceira geração, os chamados direitos transindividuais, e mesmo os de quarta geração, tema ainda novo em nosso ordenamento.

O tipo de postura contrária a esta deita raízes no pensamento liberal de Locke ${ }^{44}$ que tinha nos direitos civis e políticos o núcleo do Estado Liberal, em que estabeleceu a questão dos direitos humanos em função, exclusivamente, da propriedade. Para esse autor, o cerne dos direitos civis e políticos encontrava-se no direito de propriedade, que iria sustentar, proteger e assegurar o produto do exercício da autonomia, da liberdade e do trabalho humano. Ou seja, esse sistema primava pela liberdade e igualdade, porém, dos proprietários, pois centrado na propriedade e na conjuntura contratualista da época, o direito do Estado Liberal firmou-se no chamado império da lei e no formalismo jurídico abstrato, impedindo que nos direitos humanos fossem inseridos os direitos sociais.

Os argumentos ilusórios/ardilosos políticos e teóricos utilizados para excluir os direitos sociais do âmbito dos direitos humanos fundamentais evidenciam somente relações sociais e econômicas específicas, centradas na propriedade e na economia de mercado livre e não social, ou seja, uma postura eminentemente neoliberal.

Em verdade, existe nesse mascarado Estado Liberal ativo uma intervenção no domínio econômico que não cumpre, em nenhum momento, papel socializante, muito pelo contrário, razão pela qual entendemos que se os direitos sociais forem considerados, em sua fundamentação (mas também em sua consagração constitucional), sob um paradigma diferente daquele encontrado na teoria liberal do direito e do Estado, talvez, somente aí, a superação desse impasse no pensamento social contemporâneo poderá ser realizada.

Indubitavelmente, o Estado Democrático de Direito serve para sustentar essa fundamentação, através da democracia, implementado por indivíduos racionais, no exercício da cidadania participativa. No entanto, estamos perdidos na falta de efetividade dos preceitos constitucionais, principalmente no que diz respeito aos direitos sociais fundamentais, e a ausência de mudanças sociais significativas traz descrença ao próprio Estado, propiciando assim o fortalecimento de ideias conservadoras e neoliberais, que, denominando neocapitalistas, e através de uma globalização majoritariamente econômica, procuram manter o status quo de produção de desigualdades sociais, pautando seu ideário a partir do aperfeiçoamento da ideia de Estado mínimo, como já referido.

$\overline{44}$ LOCKE, John. Segundo tratado sobre o governo. São Paulo: Martin Claret, 2005. 
Todavia, devemos firmar definitivamente a tese de que os direitos sociais, fazendo parte dos direitos humanos fundamentais, devem ser compreendidos como direitos essenciais e inafastáveis.

Falando dessa maneira, surge a hipótese de que os ditos direitos sociais fundamentais, em vez de serem direitos contra o Estado, conforme ideia liberal, se constituem em direitos através do Estado, o que exige do Poder Público certas prestações materiais, como a implementação de políticas sociais que garantam o gozo efetivo dos direitos constitucionalmente protegidos.

Veja-se que os direitos humanos se situam, em virtude de suas características morais, acima da organização estatal, deitando suas raízes, em última instância, na consciência ética coletiva. Temos que os direitos sociais possuem as mesmas características de obrigatoriedade dos direitos humanos. A demonstração dessas características dos direitos sociais, como direitos humanos, pode ser elaborada em função da atribuição de qualidades que têm a ver com a dignidade humana.

Nessa senda é que surge a importância de abordar a noção da dificuldade de estabelecimento e asseguramento dos direitos humanos neste processo de globalização de cunho prioritariamente econômico-financeiro.

Se formos analisar os reflexos nos direitos humanos e também na democracia no âmbito da economia globalizada, e viermos a questionar qual a possibilidade de futuro positivo para aqueles, com certeza, pelo caminho que estamos trilhando, nossas respostas serão céticas.

E mais, se o poder estatal, com esse processo de globalização, é relativizado, como os direitos humanos - aqui principalmente falando-se em direitos sociais fundamentais, instrumentalizados por esse próprio Poder Público - podem ser ditos eficazes?

Com o fenômeno da globalização, no entanto, como já se viu, os poderes Legislativo, Executivo e Judiciário são funcionalmente esvaziados ou relativizados. Por isso, as três gerações de direitos humanos (os relativos à cidadania civil e política, os relativos à cidadania social e econômica, e os relativos à cidadania "pós-material" - direito à qualidade de vida, a um meio ambiente saudável, à tutela dos interesses difusos e ao reconhecimento da diferença, da singularidade e da subjetividade etc.) acabam enfrentando problemas para serem efetivadas.

As liberdades públicas, igualdade substantiva e afirmação dos interesses - que são seus valores básicos - colidem frontalmente com os imperativos categóricos da transnacionalização dos mercados, dos quais se destacam a eficácia, a produtividade e a competitividade.

O dualismo econômico e estrutural da realidade mundial e principalmente latino-americana tem sido agravado por esse processo de globalização econômica, desencadeando o aumento das desigualdades sociais e o desemprego, marcando a ferro cada vez mais a pobreza absoluta e a exclusão social. 
A exclusão socioeconômica gera reflexos graves na universalidade e indivisibilidade dos direitos humanos. $O$ alcance universal dos direitos humanos é mitigado pelo largo exército de excluídos, que se tornam supérfluos em face do paradigma econômico vigente, vivendo mais no “Estado da natureza” que propriamente no Estado Democrático de Direito.

Por sua vez, o caráter indivisível desses direitos é também mitigado pelo esvaziamento dos direitos sociais fundamentais, especialmente em virtude da tendência de flexibilização de direitos sociais básicos, que integram o conteúdo de direitos humanos fundamentais. A garantia dos direitos sociais básicos (como o direito ao trabalho, à saúde e à educação), que integram o conteúdo dos direitos humanos, tem sido apontada como um entrave ao funcionamento do mercado e um obstáculo à livre circulação do capital e à competitividade internacional.

Em razão da indivisibilidade dos direitos humanos, a violação aos direitos econômicos, sociais e culturais propicia a violação aos direitos civis e políticos, eis que a vulnerabilidade econômico-social leva à vulnerabilidade dos direitos civis e políticos. Acrescente-se ainda que esse processo de violação dos direitos humanos alcança prioritariamente os grupos sociais vulneráveis, como as mulheres e a população negra (daí os fenômenos da "feminização" e “etnicização" da pobreza).

Ou seja, urge a necessidade da ruptura com um modelo (neo)liberal-individualista, sustentáculo da globalização econômica, que visa à instalação definitiva de um modelo Estado mínimo, mencionado anteriormente, para que as camadas da população menos favorecidas, vítimas de uma sociedade caracterizada pela desigualdade social, vítimas de uma posição conservadora de Estado, de direito e mesmo de sociedade, alcancem a igualdade, fazendo valer os preceitos fundamentais constitucionais.

Isso só seria possível por meio de uma nova postura hermenêutica, que contemple a concretização do texto constitucional e, consequentemente, dos direitos fundamentais, de maneira autêntica, levando-se em consideração uma preocupação com a própria construção de uma nova ordem econômica, política e social, de modo que seja possivel diminuir as desigualdades sociais, privilegiando-se os princípios jusfundamentais, afinal, os operadores do direito devem (ou deveriam, mesmo que insistam em não fazê-lo) operar para construção do Estado Democrático de Direito.

Por fim, resta claro também que, para firmar-se a concretização do princípio da igualdade, inserido nos direitos fundamentais previstos na Carta Maior, é necessário fornecer elementos que visem garantir a consecução desse princípio, apoiando-se na ideia de surgimento de maiores oportunidades entre a parcela dita minoritária e excluída, propiciando juridicamente o embate às diferenças sociais e econômicas, verificadas ao longo do tempo.

A liberdade foi o valor que inspirou o surgimento da primeira geração de direitos humanos, todavia a liberdade em sua acepção negativa. Com efeito, a ordem liberal politicamente institucionalizada através dos direitos civis e políticos 
assegurou o estabelecimento de um sistema social em torno da economia livre de mercado, economia essa que terminou por gerar um quadro de profundas e injustas desigualdades sociais. O Estado liberal, por trás de sua aparente neutralidade, na realidade estava a serviço de uma classe social, a classe dos detentores dos meios de produção.

Nesse contexto de desequilíbrio entre as condições de vida de diferentes classes sociais, foram, assim, formuladas as reivindicações sociais que serviram de fundamentos para a segunda geração dos direitos humanos, os direitos sociais, econômicos e culturais.

Após o Estado Liberal, este é substituído pelo Estado Social de Direito, que inclui no sistema de direitos fundamentais não só as liberdades clássicas, mas também os direitos econômicos, sociais e culturais. Contudo, a ideia de igualdade social, própria do Estado Social de Direito, não se identifica com a garantia de igualdade perante a lei, mera igualdade formal. Exige, ao contrário, um outro tipo de igualdade, material, que representa exatamente a superação da igualdade jurídica do liberalismo.

Importante também referir que, em nosso Estado Democrático de Direito, os direitos fundamentais básicos estão cada vez mais dependentes da prestação de determinados serviços públicos, pois os direitos fundamentais de defesa somente podem ser eficazes quando protegem as condições materiais necessárias para a sua realização.

\section{Considerações finais}

Os direitos sociais, econômicos e culturais constituem, junto com as liberdades civis e políticas, o acesso a essa dimensão maior da liberdade. Além dos valores da igualdade e da liberdade, os direitos sociais encontram fundamento ético na exigência de justiça, na medida em que são essenciais para a promoção da dignidade da pessoa humana e indispensáveis para a consolidação do Estado Democrático de Direito, pelo qual se pretende assegurar a inclusão social, o que pressupõe participação popular e exercício dos direitos da cidadania, em que esta estabelece um vínculo jurídico entre o cidadão e o Estado.

No Estado Democrático de Direito esse vínculo é mais abrangente, pois o cidadão é aquele que goza e detém direitos civis (liberdades individuais) e políticos (participação política), mas também direitos sociais em tempo de vulnerabilidade.

A sociedade preocupa-se que o indivíduo sobreviva dignamente, mostrando que somente um cidadão poderá ser responsável quando a comunidade política tiver demonstrado de maneira hialina que reconhece esse mesmo indivíduo como membro dessa sociedade, garantindo seus direitos sociais humanos/fundamentais básicos.

Tentamos demonstrar neste trabalho que a elaboração de referenciais aptos a uma mudança de paradigma de direito e de noção de Estado é fundamental, superando-se as posições mais conservadoras, que impedem um desvelamento dos 
conceitos de Estado e do direito, que não mais condizem com as necessidades da coletividade, da cidadania, de modo que os operadores jurídicos passem a utilizar a Constituição Federal e o direito como instrumento de efetivação das garantias e direitos fundamentais, inclusive os sociais, com base nos princípios da igualdade material e dignidade da pessoa humana presentes em nossa Constituição, carta maior de um Estado considerado Democrático de Direito.

Temos que ter claro o argumento de que os direitos sociais fundamentais adquiriram um novo papel em nosso sistema jurídico, deixando, há muito, de serem meros instrumentos formais, destinados a compensar situações de desigualdade, e passando a atuar como núcleos integradores e legitimadores do bem comum, pois será através deles que se poderá garantir a segurança, a liberdade, a sustentação e a continuidade da sociedade humana.

Por isso, se torna sempre justificável abordar as dificuldades encontradas para a efetivação do princípio da dignidade da pessoa humana, bem como o princípio constitucional da igualdade, matrizes de políticas públicas que visam à inclusão social.

The effect of the crisis interconnected of the contemporary state in the transformation of the social fundamental human rights

Abstract: The purpose of this article is to show how crises undergone by the contemporary state influence the effectiveness of Fundamental Social Rights, and the principles of human dignity, and especially the principle of equality. With this, hopes to demonstrate that the fundamental rights may come in the form of constitutional principles or rules, and that the equality, as a first dimension fundamental right, cannot be understood by a purely formal subjective logic, inherent to liberalism. The conclusion is that it's necessary that the State abandons a position of neutrality, which has a well proved insufficiency, and start to promote an material-objective equality.

Keywords: Crisis of the State. Fundamental rights. Equality principle.

\section{Referências}

BARROSO, Luis Roberto. O direito constitucional e a efetividade de suas normas. Rio de Janeiro: Renovar, 2006.

BAUMAN, Zygmunt. Modernidade líquida. Rio de Janeiro: Jorge Zahar, 2001.

BOBBIO, Norberto. Dicionário de política. Brasília: UnB, 1986.

BOBBIO, Norberto. O futuro da democracia. 7. ed. rev. e ampl. Tradução de Marco Aurélio Nogueira. São Paulo: Paz e Terra, 2000.

BONAVIDES, Paulo. Curso de direito constitucional. 12. ed. São Paulo: Malheiros, 2003.

CAMPILONGO, Celso Fernandes. $O$ trabalhador e o direito à saúde: a eficácia dos direitos sociais e o discurso neoliberal. São Paulo: Revista dos Tribunais, 1995.

CAMPILONGO, Celso Fernandes. Os desafios do Judiciário: um enquadramento teórico. In: FARIA, José Eduardo (Org.). Direitos humanos, direitos sociais e justiça. São Paulo: Malheiros, 1994. 
CANOTILHO, José Joaquim Gomes. Direito constitucional e teoria da Constituição. 2. ed. Coimbra: Almedina, 1998.

FARIA, José Eduardo. O direito na economia globalizada. 1. ed. 3. tir. São Paulo: Malheiros, 2002.

FERRAJOLI, Luigi. A soberania no mundo moderno: nascimento e crise do Estado nacional. Tradução de Carlo Coccioli e Márcio Lauria Filho. São Paulo: Martins Fontes, 2002.

KRELL, Andreas Joachim. Direitos sociais e controle judicial no Brasil e na Alemanha: os descaminhos de um direito constitucional "comparado". Porto Alegre: Sergio Antônio Fabris Editor, 2002.

MARTÍN-RETORTILL, Lorenzo. Regimen constitucional de los derechos fundamentales. In: MARTíNRETORTILL, Lorenzo; DE OTTO Y PARDO, I. Derechos fundamentales y Constitución. Madrid: Civitas, 1988.

MIRANDA, Jorge. Manual de direito constitucional. 3. ed. Coimbra: Coimbra Editora, 2000. v. IV.

MORAIS, José Luís Bolzan de. De sonhos feitos, desfeitos e refeitos vivemos a globalização. In: SARLET, Ingo Wolfgang. Direitos fundamentais sociais: estudos de direito constitucional, internacional e comparado. Rio de Janeiro: Renovar, 2003

MORAIS, José Luiz Bolzan de. As crises do Estado e da Constituição e a transformação espacial dos direitos humanos. Porto Alegre: Livraria do Advogado, 2002.

PIOVESAN, Flávia. Organismos e procedimentos internacionais de proteção dos direitos econômicos, sociais e culturais. Rio de Janeiro: PUC-Rio, 2002.

SANTOS, Boaventura de Sousa. A crítica da razão indolente - Contra o desperdício da experiência. São Paulo: Cortez, 2000.

SILVA, José Afonso da. Curso de direito constitucional positivo. São Paulo: Malheiros, 2001.

STRECK, Lenio Luiz. Hermenêutica jurídica e $(m)$ crise - Uma exploração hermenêutica da construção do Direito. 3. ed. Porto Alegre: Livraria do Advogado, 2001.

STRECK, Lenio Luiz. Jurisdição constitucional e hermenêutica - Uma nova crítica do direito. Porto Alegre: Livraria do Advogado, 2002.

STRECK, Lenio Luiz; MORAIS, José Luis Bolzan de. Ciência política e teoria geral do Estado. 2. ed. Porto Alegre: Livraria do Advogado, 2001.

TORRES, Ricardo Lobo. A cidadania multidimensional na era dos direitos. In: TORRES, Ricardo Lobo (Org.). Teoria dos direitos fundamentais. 2. ed. Rio de Janeiro: Renovar, 2001.

Informação bibliográfica deste texto, conforme a NBR 6023:2002 da Associação Brasileira de Normas Técnicas (ABNT):

SCHNEIDER, Yuri; SILVA, Rogério Luiz Nery da. O reflexo das crises interconectadas do Estado contemporâneo na transformação dos direitos humanos fundamentais sociais. A\&C - Revista de Direito Administrativo \& Constitucional, Belo Horizonte, ano 16, n. 63, p. 137-164, jan./mar. 2016. 